\title{
Streptococcus pneumoniae nasopharyngeal colonisation in children aged under six years with acute respiratory tract infection in Lithuania, February 2012 to March 2013
}

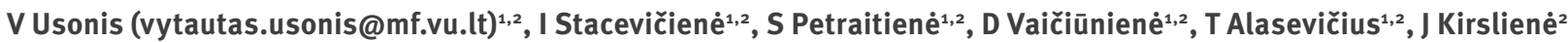

1. Vilnius University, Clinic of Children's Diseases, Vilnius, Lithuania

2. Children's Hospital, Affiliate of Vilnius University Hospital Santariskiu Klinikos, Vilnius, Lithuania

Usonis V, Stacevičienė I, Petraitienè S, Vaičiūnienė D, Alasevičius T, Kirslienė J. Streptococcus pneumoniae nasopharyngeal colonisation in children aged under six years with acute respiratory tract infection in Lithuania, February 2012 to March 2013. Euro Surveill. 2015;20(13):pii=21079. Available online: http://www. eurosurveillance.org/ViewArticle.aspx?Articleld=21079

Article submitted on 19 February 2014 / published on 02 April 2015

Data on distribution of Streptococcus pneumoniae (SPn) serotypes among children in Lithuania are limited. A prospective study was carried out from February 2012 to March 2013 to evaluate the circulation of SPn serotypes among young children in five cities of Lithuania before the introduction of universal vaccination with pneumococcal conjugate vaccine (PCV). A total of 900 children under six years of age who presented to primary care centres or a hospital emergency department with acute respiratory tract infection (RTI) were enrolled in the study. The SPn colonisation rate was $40.8 \%(367 / 900)$, with a peak at two and three yearsold ( $48.8 \%$ and $45.4 \%$, respectively). Of the $367 \mathrm{SPn}$ isolates, the most common serotypes were $6 \mathrm{~B}(15.8 \%$, $\mathrm{n}=58), 19 \mathrm{~F}(13.9 \%, \mathrm{n}=51), 23 \mathrm{~F}(13.9 \%, \mathrm{n}=51), 15$ $(10.1 \%, n=37), 14(9.5 \%, n=35), 6 A(9.3 \%, n=34)$, $11(4.6 \%, n=17), 3(3.0 \%, n=11)$ and $18 C(3.0 \%, n=$ $11)$; less frequent were 23 (non-23F) $(2.7 \%, n=10), 19 A$ $(2.2 \%, n=8)$ and $9 V(1.6 \%, n=6)$. Serotypes $6 A$ and 11 were more common in children under two years-old; $18 \mathrm{C}$ was found only in children aged two to five years. The serotypes found might be an important predictor of the likely effectiveness of the PCVs currently available in Lithuania

\section{Introduction}

Streptococcus pneumoniae (SPn) is one of the major bacterial pathogens colonising the nasopharynx, which can cause a wide spectrum of illnesses from upper respiratory tract infection (RTI) to invasive pneumococcal disease (IPD), or the infection can be asymptomatic [1]. SPn infection is also associated with high mortality an estimated 1.6 million people, including $0.7-1$ million children under five years of age, die of pneumococcal diseases each year worldwide [2].

Pneumococcal disease is preceded by asymptomatic colonisation: the colonisation rate is especially high in children under six years of age $[1,3]$. In addition, nasopharyngeal carriage is a major factor in the horizontal transmission of SPn strains and nasopharyngeal isolates reflect currently circulating strains in the community [4]. Young children are thought to be the most important source in horizontal dissemination of pneumococcal strains due to the high frequency of pneumococcal colonisation and high crowding in day-care centres and families [1].

There is a wide variation in SPn capsule polysaccharides: currently 94 serotypes have been identified [5]. Different SPn serotypes have different propensities to cause disease [6]. The distribution of SPn serotypes varies by country, age or ethnic group, and study design [4,7-13]. Data on distribution of SPn serotypes among children in Lithuania are limited. The National Public Health Surveillance Laboratory in Vilnius collects all invasive pneumococcus strains nationwide. A total of 45 SPn strains, which caused IPD in children under five years of age, were serotyped during 2006 to 2011. Some 14 different serotypes were identified, with $23 \mathrm{~F}, 14,6 \mathrm{~B}, 1,18 \mathrm{C}$ being the most prevalent serotypes [14]. As the amount of data was low, however, the findings do not necessarily reflect the actual SPn serotype prevalence among IPD paediatric patients in Lithuania.

The presence of SPn in the nasopharynx of children with acute RTI might be considered as an additional risk factor for development of mucosal or invasive pneumococcal disease [15]; however, data on the carriage rate and SPn serotype distribution among such patients worldwide are limited. The data in our study will be analysed further to evaluate whether the presence of SPn in the nasopharynx had an influence on the outcome of acute RTI among our patients.

At the time of the study, routine PCV vaccination was not yet part of the national vaccination schedule in Lithuania and PCVs (10-valent (PCV10) and 13-valent 
Demographic data of enrolled children under six years of age with acute respiratory tract infection in the study sites, Lithuania, February 2012 to March 2013 (n=900)

\begin{tabular}{|c|c|c|c|c|c|c|c|c|}
\hline \multirow{3}{*}{ Characteristic } & \multicolumn{8}{|c|}{ Number (\%)a } \\
\hline & \multicolumn{3}{|c|}{ Vilnius } & \multirow{2}{*}{$\begin{array}{c}\text { Kaunas } \\
\text { PCC }\end{array}$} & \multirow{2}{*}{$\begin{array}{c}\text { Klaipeda } \\
\text { PCC }\end{array}$} & \multirow[t]{2}{*}{ Panevezys } & \multirow{2}{*}{$\begin{array}{c}\text { Alytus } \\
\text { PCC }\end{array}$} & \multirow{2}{*}{ Total } \\
\hline & PCC & ED & Total & & & & & \\
\hline Children enrolled & $173(19.2)$ & $264(29.3)$ & $437(48.6)$ & $159(17.7)$ & $63(7.0)$ & $223(24.8)$ & $18(2.0)$ & $900(100)$ \\
\hline \multicolumn{9}{|l|}{ Sex } \\
\hline Female & $84(48.6)$ & $110(41.7)$ & $194(44.4)$ & $78(49.1)$ & $28(44.4)$ & $104(46.6)$ & $4(22.2)$ & $408(45.3)$ \\
\hline Male & $89(51.4)$ & $154(58.3)$ & $243(55.6)$ & $81(50.9)$ & $35(55.6)$ & $119(53.4)$ & $14(77.8)$ & $492(54.7)$ \\
\hline \multicolumn{9}{|l|}{ Age in months } \\
\hline Range & $4-69$ & $1-71$ & $1-71$ & $1-71$ & $5-71$ & $1-71$ & $23-71$ & $1-71$ \\
\hline Mean (SD) & $32.3(16.3)$ & $33.5(16.4)$ & $33.1(16.4)$ & $33.6(18.9)$ & $38.8(18.5)$ & $37.9(17.6)$ & $51.6(16.1)$ & $35.1(17.6)$ \\
\hline \multicolumn{9}{|c|}{ Age groups in months } \\
\hline $0-24$ & $57(32.9)$ & $87(33.0)$ & $144(33.0)$ & $58(36.5)$ & $14(22.2)$ & $55(24.7)$ & $1(5.6)$ & $272(30.2)$ \\
\hline $25-48$ & $86(49.7)$ & $128(48.5)$ & $214(49.0)$ & $67(42.1)$ & $29(46.0)$ & $102(45.7)$ & $7(38.9)$ & $419(46.6)$ \\
\hline 49-71 & $30(17.3)$ & $49(18.6)$ & $79(18.1)$ & $34(21.4)$ & $20(31.7)$ & $66(29.6)$ & $10(55.6)$ & $209(23.2)$ \\
\hline
\end{tabular}

ED: emergency department of Children's Hospital, Affiliate of Vilnius University Hospital Santariskiu Klinikos ; PCC: primary care centre; SD: standard deviation.

a Unless otherwise indicated.

(PCV13)) were available only on private market. As vaccination costs were not reimbursed, vaccination coverage was unknown but was probably rather low due to the relatively high price of the vaccines.

The nasopharynx is the reservoir for SPn and the carriage of SPn in children with acute RTI has not been studied widely. This study was undertaken to evaluate the circulation of SPn serotypes among children with acute RTI under six years of age in Lithuania before the introduction of universal pneumococcal vaccination in the country in October 2014 [16]. It was expected that the data collected will be helpful in decision-making regarding universal PCV vaccination in Lithuania. They may also be the basis for further investigations into the impact of PCV vaccination on the distribution of SPn serotypes in Lithuania, including the widely discussed phenomenon of replacement, i.e. changes in circulating SPn serotypes due to vaccination [17].

\section{Methods}

This prospective study was carried out from February 2012 to March 2013. Eight primary care centres in Lithuania's five biggest cities (Vilnius $(n=2)$, Kaunas $(n=2)$, Klaipeda $(n=2)$, Panevezys $(n=1)$, Alytus $(n=$ 1)), from all main regions of the country, and the emergency department (ED) of Children's Hospital, Affiliate of Vilnius University Hospital Santariskiu Klinikos in Vilnius were involved in examining children for SPn nasopharyngeal carriage.

Children under six years old, who visited a primary care physician because of acute RTI and who met all inclusion criteria were enrolled into the study. The main symptoms of acute RTI were acute onset, fever, runny nose, cough, throat redness and otalgia. Children were excluded if they had been vaccinated with any pneumococcal vaccine, had taken antibiotics during the previous month or another cause of fever was identified (e.g. it was confirmed not due to respiratory infection).

Local ethics committee approval was obtained and the parents were asked to sign an informed consent form before the child was enrolled in the study.

Nasopharyngeal swabs were taken at the time of enrolment in the study using Culturette with Amies transport medium (Deltalab, Spain) and transported to the bacteriology laboratory of Children's Hospital, Affiliate of Vilnius University Hospital Santariskiu Klinikos in Vilnius within 48 hours from collection. Classic cultural methods (cultivation in $5 \% \mathrm{CO}_{2}$, colony morphology, optochin sensitivity) were used to isolate SPn from the swabs [18]. Serotypes were determined by means of latex agglutination reaction using the PneumotestLatex kit (Statens Serum Institut, Copenhagen, Denmark).

\section{Statistical analysis}

The data were analysed using SPSS software 16 . Chisquared test was used to test statistical significance for differences between two groups. Fisher's exact test was used when cell values in the SPSS table had an expected frequency of five or less. Statistical significance was defined by $p<0.05$.

The expected theoretical protection of PCVs was calculated by comparing the isolated SPn serotypes with the serotypes included in currently available PCV vaccines. 
Streptococcus pneumoniae nasopharyngeal colonisation among enrolled children aged under six years with acute respiratory tract infection in the study sites, Lithuania, February 2012-March 2013 (n=900)

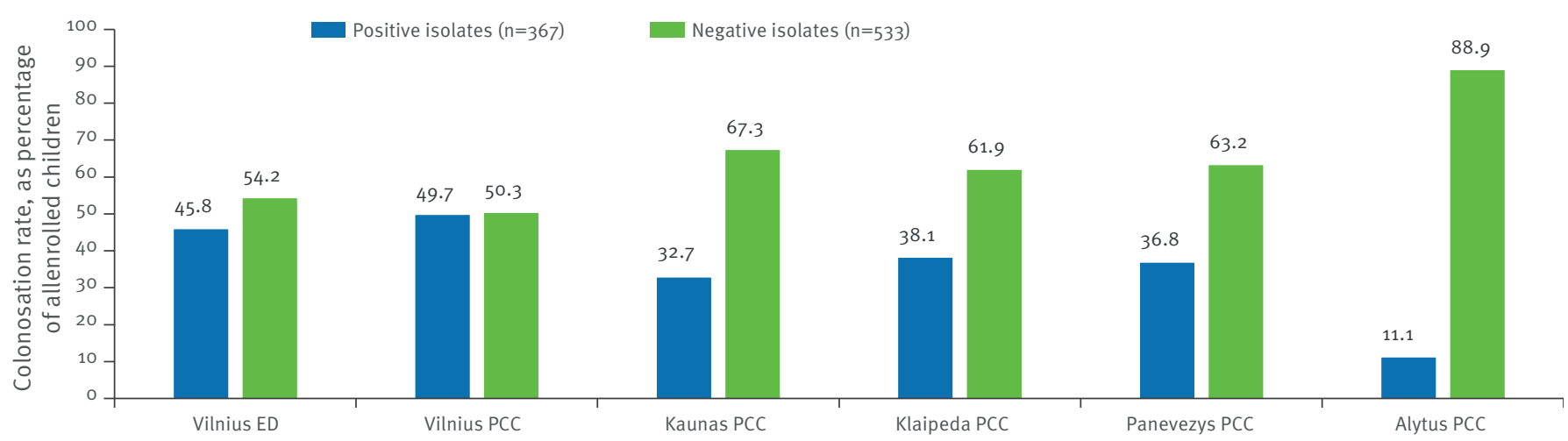

ED: emergency department of Children's Hospital, Affiliate of Vilnius University Hospital Santariskiu Klinikos ; PCC: primary care centre.

Multivariable Poisson regression with robust variance estimation was used to assess the association of site, season, age and sex with SPn colonisation. SPn colonisation prevalence ratios (PRs) with $95 \%$ confidence intervals (Cls) associated with the site (PCC of Vilnius, Kaunas, Klaipeda, Alytus and Panevezys vs Vilnius ED), season (spring vs winter, summer vs winter, and autumn vs winter), sex (female vs male), and age (2548 vs $1-24$ months and 49-71 vs $1-24$ months) were calculated.

\section{Results}

During the one-year study period, 908 children were examined for SPn nasopharyngeal carriage. Due to the exclusion criteria, eight were excluded from the analysis. The data collected from the 900 study participants were analysed: 636 patients at the PCCs and 264 at the hospital ED.
The enrolled children comprised 408 girls and 492 boys under six years of age with acute RTI. The participants were enrolled throughout the study period. Two thirds were enrolled during spring and autumn (35.0\% $(n=315)$ and $32.9 \%(n=296)$, respectively), the others during winter $(22.0 \%(n=198)$ and summer $(10.1 \%(n$ $=91)$ ). The distribution of enrolled children by sex and age was similar in all the cities, with the exception of Alytus (Table), which may be due to a very small number of study participants in this city $(n=18)$.

\section{Streptococcus pneumoniae colonisation rate}

A total of 367 SPn strains (one per patient) were isolated from the 900 samples collected, giving a colonisation rate of $40.8 \%$. The rate was higher among patients admitted to the ED of the Children's Hospital in Vilnius than among patients at the PCCs $(45.8 \%(121 / 264)$ vs $38.7 \%(246 / 636) ; p=0.047)$. The colonisation rate was

\section{FIGURE 2}

Most common Streptococcus pneumoniae serotypes isolated from enrolled children aged under six years with acute respiratory tract infection the study sites ${ }^{\mathrm{a}}$, Lithuania, February 2012-March 2013 (n=367)

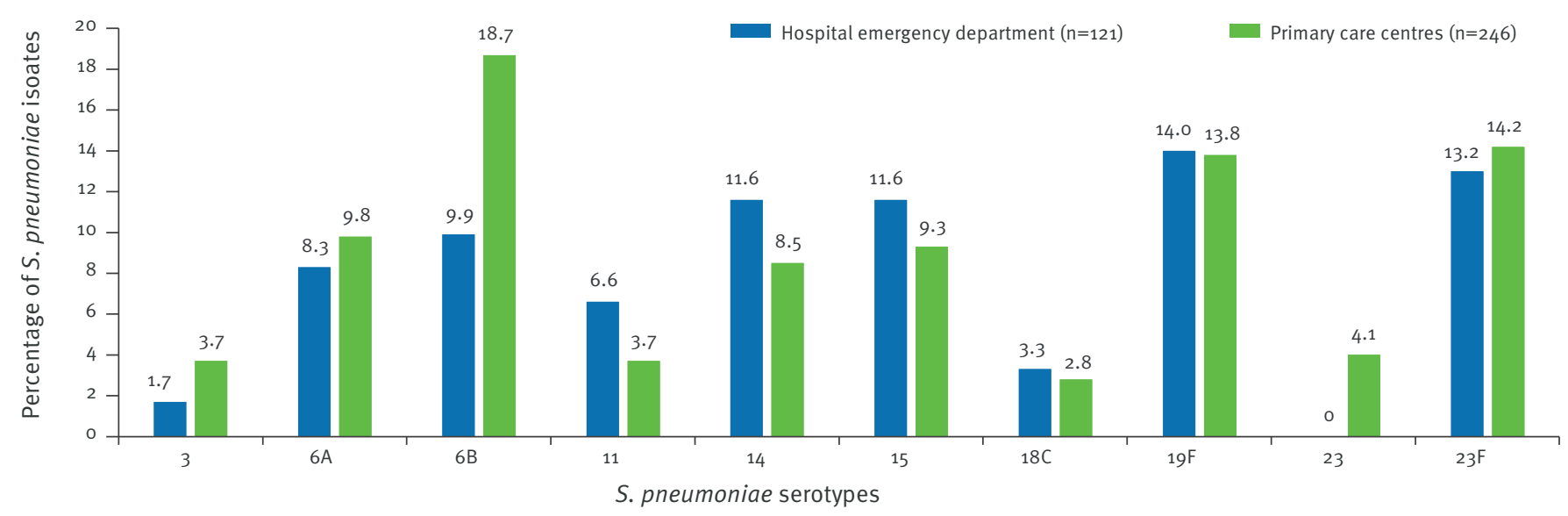

Study sites were primary care centres of Vilnius, Kaunas, Klaipeda, Panevezys and Alytus and the emergency department of Children's Hospital, Affiliate of Vilnius University Hospital Santariskiu Klinikos in Vilnius. 
Distribution of the most common Streptococcus pneumoniae serotypes isolated from enrolled children aged under six years with acute respiratory tract infection in the study sites ${ }^{\mathrm{a}}$, Lithuania, February 2012-March 2013 ( $\left.\mathrm{n}=365\right)$

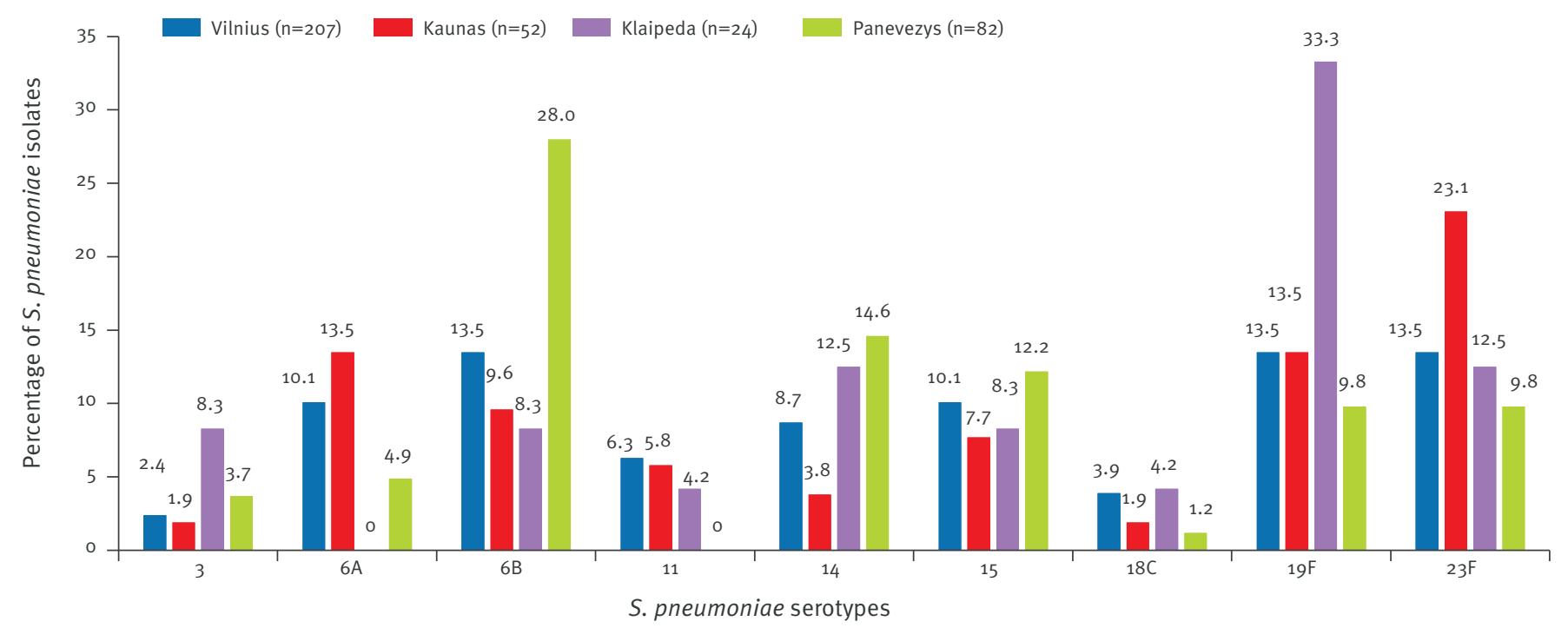

Study sites were primary care centres of Vilnius, Kaunas, Klaipeda, Panevezys and Alytus and the emergency department of Children's Hospital, Affiliate of Vilnius University Hospital Santariskiu Klinikos in Vilnius. Note that Alytus was excluded from this comparison because of the small number of $S$. pneumoniae isolates $(n=2)$.

higher in Vilnius PCC and ED $(47.4 \%, 207 / 437)$ than in Kaunas (32.7\%, 52/159; $p=0.001)$, Panevezys (36.8\%, $82 / 223 ; p=0.009)$ and Alytus (2/18; $p=0.002)$.

There was also a higher colonisation rate in Vilnius (both PCC and ED) than in Klaipeda (38.1\%, 24/63), but the difference was not statistically significant $(p=0.168)$. The distribution of pneumococcal colonisation rates in the enrolled children in the five cities in Lithuania is shown in Figure 1.

Seasonality differences were detected in SPn colonisation rates: they were higher in spring $(43.2 \%, 136 / 315)$ and autumn $(44.6 \%, 132 / 296)$ than in summer $(35.2 \%$ (32/91), p>0.05 for both comparisons) and winter (33.8\% (67/198), $p=0.035$ and $p=0.017$, respectively). The sex of the patients had no influence on the pneumococcal colonisation rates: $40.4 \%(165 / 408)$ of the girls and $41.1 \%(202 / 492)$ of the boys carried SPn in their nasopharynx.

The youngest child with a positive pneumococcal sample was two months-old. The colonisation rate of SPn in infants aged up to one year was $28.0 \%$ (26/93). A peak level was reached at two to three years of age (48.8\% (101/207) and 45.4\% (98/216), respectively). A slight decrease in the colonisation rate was found among children aged four to five years (38.1\% (45/118) at the age of four years and $30.7 \%(31 / 101)$ at the age of five years).

Using multivariable Poisson regression analysis, the prevalence of SPn colonisation was higher in children aged 25-48 months (PR: 1.301), but not in children aged 49-71 months (PR: 0.986), compared with children aged up to 24 months. The PCCs of Kaunas, Alytus and Panevezys had significantly lower colonisation rates than the Vilnius ED (PR: 0.689 for Kaunas PCC vs ED, PR: 0.241 for Alytus PCC vs ED, and PR: 0.775 for Panevezys vs ED). The Vilnius PCC had similar colonisation rates as the Vilnius ED (PR: 1.046) and there were no significant differences between Klaipeda PCC and the Vilnius ED (PR: 0.768). The colonisation rate was significantly higher during autumn than winter (PR: 1.355), but not during other the seasons (PR: 1.262 for spring vs winter and PR: 0.950 for summer vs winter).

Streptococcus pneumoniae serotype distribution Of the 367 SPn strains isolated, 22 different serotypes were detected. The most common serotypes were $6 \mathrm{~B}$ (15.8\%, $\mathrm{n}=58), 19 \mathrm{~F}(13.9 \%, \mathrm{n}=51), 23 \mathrm{~F}(13.9 \%, \mathrm{n}=$ 51), $15(10.1 \%, n=37), 14(9.5 \%, n=35), 6 A(9.3 \%, n=$ $34), 11(4.6 \%, n=17), 3(3.0 \%, n=11)$ and $18 C(3.0 \%$, $n=11)$. Other SPn serotypes constituted $16.9 \%(n=62)$ of all isolates and were as follows: serotypes 23 (non$23 \mathrm{~F})(2.7 \%, \mathrm{n}=10), 19 \mathrm{~A}(2.2 \%, \mathrm{n}=8), 9 \mathrm{~V}(1.6 \%, \mathrm{n}=6)$, $9(1.1 \%, n=4), 10(1.1 \%, n=4), 22(0.8 \%, n=3), 6 C$ $(0.5 \%, n=2)$ and single isolates of $4,7,7 \mathrm{~F}, 12,17$ and 19 serotypes; $5.2 \%(n=19)$ were non-typable.

Differences in the distribution of SPn serotypes between those isolated from patients at the Vilnius ED and the PCCs were not statistically significant, except for serotypes $6 \mathrm{~B}$ and 23 , which were more common at the PCCs $(p=0.03$ and $p=0.034$, respectively) (Figure 2). 
Distribution of Streptococcus pneumoniae serotypes by age group of enrolled children aged under six years with acute respiratory tract infection in the study sites ${ }^{a}$, Lithuania, February 2012-March 2013 (n=367)

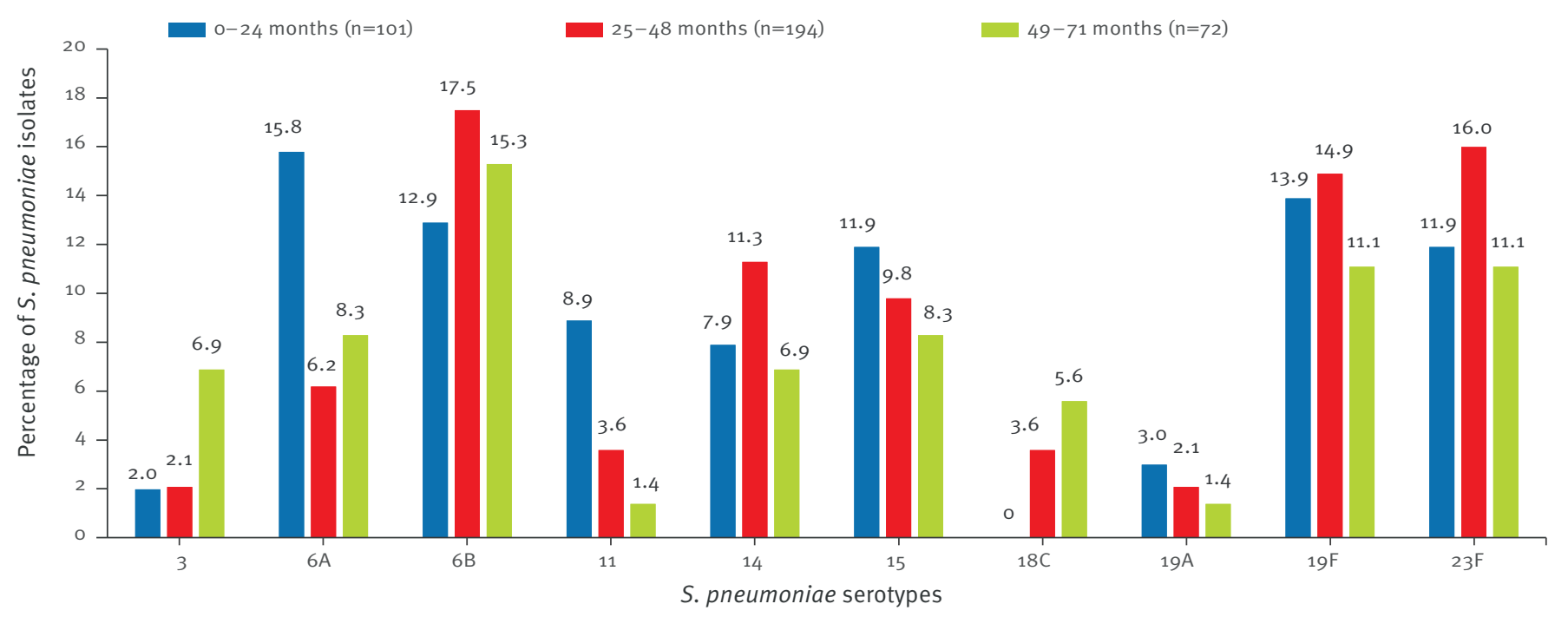

Study sites were primary care centres of Vilnius, Kaunas, Klaipeda, Panevezys and Alytus and the emergency department of Children's Hospital, Affiliate of Vilnius University Hospital Santariskiu Klinikos in Vilnius.

A slightly different distribution of SPn serotypes was found in the study sites (Figure 3). Serotype 6B was more prevalent in Panevezys, compared with Vilnius $(p=0.004)$, Kaunas $(p=0.011)$ and Klaipeda $(p=0.045)$. Serotype $19 \mathrm{~F}$ was more common in Klaipeda, compared with Vilnius $(p=0.018)$ and Panevezys $(p=0.009)$. Serotype $23 \mathrm{~F}$ was more prevalent in Kaunas, compared with Panevezys $(p=0.035)$. Serotype 6A was not found in Klaipeda but was observed in Vilnius, Kaunas, Panevezys and Alytus; serotype 11 was not found in Panevezys but was identified in the other cities studied. Alytus was excluded from this comparison because of the small number of SPn isolates $(n=2)$.

The prevalence of serotypes $6 \mathrm{~B}, 19 \mathrm{~F}$ and $23 \mathrm{~F}$ varied during the seasons. Serotype 6B was more prevalent during autumn $(22.0 \%(29 / 132)$ and winter $(19.4 \%(13 / 67)$ as compared with spring ( $11 \%(15 / 136), p=0.018$ and $p=0.108$, respectively) and summer $(1 / 32, p=0.014$ and $p=0.03$, respectively). Conversely, serotype $19 \mathrm{~F}$ reached a peak $(8 / 32)$ during summer; serotype $23 \mathrm{~F}$ peaked during spring $(21.3 \%, 29 / 136)$. The fluctuation rates of other SPn serotypes according to the season were not statistically significant. The numbers are small, however, thus limiting the ability to meaningfully compare between the seasons.

Of the 165 isolates from girls, serotypes $6 \mathrm{~B}(20.0 \%, \mathrm{n}=$ $33), 23 F(12.7 \%, n=21), 19 F(10.9 \%, n=18), 15(10.3 \%$, $n=17), 6 A(9.7 \%, n=16)$ and $14(9.7 \%, n=16)$ were the most common, whereas of the 202 isolates from boys, serotypes $19 \mathrm{~F}(16.3 \%, \mathrm{n}=33), 23 \mathrm{~F}(14.9 \%, \mathrm{n}=30), 6 \mathrm{~B}$ $(12.4 \%, \mathrm{n}=25), 15(9.9 \%, \mathrm{n}=20), 14(9.4 \%, \mathrm{n}=19)$ and $6 \mathrm{~A}(8.9 \%, \mathrm{n}=18)$ were the most common. There were no sex-related differences, except for $6 \mathrm{~B}$, which was more common in girls $(p=0.046)$.

In addition, the study showed an age-related SPn serotype distribution, with serotypes $6 \mathrm{~A}$ and 11 being more common in the youngest age group (0-2 years), while $18 \mathrm{C}$ was found only in the older age groups (Figure 4).

Among all serotypes isolated from our 367 patients, $58 \%(n=214)$ were present in $\mathrm{PCV}_{10}$ (serotypes 1,4 , $5,6 \mathrm{~B}, 7 \mathrm{~F}, 9 \mathrm{~V}, 14,18 \mathrm{C}, 19 \mathrm{~F}$ and $23 \mathrm{~F})$ and $73 \%(\mathrm{n}=267)$ in $\mathrm{PCV}_{13}$ (serotypes $1,3,4,5,6 \mathrm{~A}, 6 \mathrm{~B}, 7 \mathrm{~F}, 9 \mathrm{~V}, 14,18 \mathrm{C}$, $19 \mathrm{~A}, 19 \mathrm{~F}$ and $23 \mathrm{~F}$ ).

\section{Discussion}

Data concerning the SPn nasopharyngeal carriage rates among healthy children in eastern Europe, including Lithuania, are limited. During the last decades, a number of studies on SPn nasopharyngeal carriage in healthy children were performed in western and southern Europe, with carriage rates ranging from $14.9 \%$ to $58.5 \%[8,10,11,13]$. The reported rates of pneumococcal carriage among healthy children under eight years of age varied, with a wide range from $3.5 \%$ to $97 \%$ among different studies worldwide $[19,20]$. Surprisingly low carriage rates $(3.5-14.9 \%)$ were observed in a few Italian studies performed in 1996 and 1999 [10,19], whereas much higher rates were seen in Romania ( $51 \%$ during 2008-09) [12], France (54\% in 1999) [8], Russia (60\% in 2007) [21] and Norway (77.7\% in 2006) [22]. The highest SPn carriage rates among healthy children (70-97\%) have been found in some Asian and African countries, e.g. in India (70.2\% in 1998-99) [23], Gambia (97\% in 2004-06) [20] and Malawi (84\% in 1997) [24]. 
In Mozambique in 2003, SPn carriage was more common among children who had lower RTI symptoms at the time of enrolment (93\%) than among healthy children (84\%) [25].

Three studies of SPn nasopharyngeal carriage in healthy children have been performed in Lithuania (in 1999, 2001 and 2006) [26-28], in which a total of 1,625 children from the same 13 day-care centres were enrolled. On average, SPn was found in the nasopharynx of every second child (51\% in 1999, 55\% in 2001 and $43 \%$ in 2006) and the most prevalent serotypes were $19 \mathrm{~F}, 23 \mathrm{~F}, 6 \mathrm{~B}, 6 \mathrm{~A}, 3$ and $18 \mathrm{C}$. These studies were rather limited because all of them were performed during a short period of time (in February and March) and the data presented were from only one city of the country (Vilnius).

In our findings presented here, the SPn colonisation rate among young children with acute RTI in the study sites in Lithuania was $40.8 \%$. It is important to note that most studies have focused on SPn carriage in healthy children while in our study, children with RTI were enrolled. The carriage rate seen was similar to those observed in healthy children in Estonia (44\%), Czech Republic (38.1\%) and Hungary (37.71\%) [9,29,30]. It is also similar to those reported in healthy children in Vilnius in 2006 (43\%) and slightly lower than that in 1999 and 2001 (51\% and 55\%, respectively) [26-28].

Different findings are reported concerning SPn nasopharyngeal colonisation among children with RTI. For example, Revai et al. (Texas, United States, in 200307) reported a relatively low SPn carriage rate (34\%) in children with upper RTI [31]. Conversely, Syrjänen et al. (Finland in 1994-97) showed that nasopharyngeal SPn carriage rates increased during respiratory infections from $13-43 \%$ to $45-56 \%$, depending on age [32]. It has also been shown that the SPn carriage rate during the first days of acute RTI is comparable to that in healthy children [33]. However, in RTI patients carrying SPn, a more severe course of RTI or activation of pneumococcal disease can occur and this is a subject for further analysis of our data.

Commonly, SPn nasopharyngeal colonisation begins in infancy, with peak incidence occurring at two to three years of age and decreases among children over the age of four to five years $[12,13,20]$. Pneumococcal colonisation occurs earlier in developing countries as compared with developed ones: high SPn carriage rates (70-98\%) have been observed in infants in some Asian and African countries such as India $(70.2 \%$ in 1998-99), Gambia (97\% in 2004-06) and Kenya (98\% in 2004) $[20,23,34]$, in contrast to Finland, where only 9-22\% of infants were colonised by SPn (1994-97) [32].

We found a seasonal fluctuation in the rates of SPn nasopharyngeal colonisation, with an increase during spring and autumn. Similarly, spring appeared to be a favourable season for SPn colonisation in comparison to winter in Poland [35] or winter in the United States [36]. In contrast, there was a reported increase of pneumococcal carriage in winter in Israel [37]. Other studies have found the seasonal effect to be negligible or absent $[38,39]$. Social factors such as being longer inside in day-care centres and higher crowding during the winter season or higher air pollution can be speculated as additional factors leading to higher colonisation rates.

In our study, the most predominant colonising serotypes were $6 \mathrm{~B}, 19 \mathrm{~F}, 23 \mathrm{~F}, 15,14$ and $6 \mathrm{~A}$, which accounted $72.5 \%$ of the isolates. Previously reported data on SPn colonisation show that serogroups 6, 19 and 23 were the most common before widespread use of PCV routine vaccination in other European countries such as Estonia, Poland, Italy, Hungary, Romania, France and the Netherlands [4,7-12]. Serotypes 19F, 23F and 6B were also predominant among nasopharyngeal isolates in healthy Lithuanian children in 2006 [26,27].

SPn serotype fluctuation has been observed during different study years in Lithuania. The prevalence of serotype 3 decreased from $13 \%$ in 1999 to $3 \%$ in our study, while serotype 14 became three times more common than in 2006 according to our data $3.2 \%$ and $9.5 \%$, respectively). Serotype 15 constituted $9 \%$ of all isolated pneumococci in 1999; it was $2.5 \%$ in 2006 $[26,27]$ and $10 \%$ in our study. The distribution of other SPn serotypes remained stable, with small differences in their rates. It is important to note, however, that the study sites and the type of children studied differed, which limit the comparison.

Although the data on SPn serotypes in children with IPD in Lithuania are rather limited, we have tried to compare the serotype distribution among IPD patients and nasopharyngeal carriers. Serotypes $23 \mathrm{~F}, 14,6 \mathrm{~B}$, commonly found in the nasopharynx in our study, were the most prevalent among all SPn isolates from children with IPD identified during 2006 to 2011 in Lithuania [14]. Serotypes 1 and 18C each constituted $8.9 \%$ of the invasive isolates [14], $18 \mathrm{C}$ was three times less common $(3.0 \%, 11 / 367)$ and serotype 1 was absent in nasopharyngeal carriage in our study. According to data reported by other authors, serotype 1 is among the most commonly isolated serotypes in IPD but it is rarely found among nasopharyngeal carriers [40].

Age-related differences of pneumococcal serotype distribution were found in our study, with serotypes $6 \mathrm{~A}$ and 11 being more common in the youngest children, while $18 \mathrm{C}$ was found only in the older age groups. A study conducted by Bogaert et al. in 2002 showed an age-related serotype distribution in healthy children in the Netherlands, with a primary peak of serotypes included in the seven-valent conjugate vaccine (PCV7) at the age of one year, followed by a secondary peak of non-vaccine serotypes at the age of four years [13]. However, few data are available concerning SPn 
serotype distribution in the nasopharynx according to age.

The serotypes found in a population might be an important predictor of the likely effectiveness of a pneumococcal vaccine in that population. Our findings suggest a rather high theoretical coverage $(58-73 \%)$ of nasopharyngeal pneumococcal isolates by the currently available PCVs (PCV-10 and PCV-13). This is similar to the theoretical coverage reported in Estonia (64\% in 1999-2000, 2003), Hungary (55.6-69.6\% in 2009-10) and Italy $(56.5 \%$ in 1999) $[9,10,30]$. Lower theoretical coverage by PCVs has been reported in the Netherlands (41.6\% in 2002), Norway (37\% in 2006) and Russia (45\%, published 2007 ) $[21,22,41]$. Conversely, PCV coverage rates were estimated to be higher in Romania (66-80\% in 2008-09), France $(76.5 \%$ in 1999$)$ and Poland $(73 \cdot 7-80.1 \%$ in $2002-03)[4,8,12]$.

As our study was performed before the implementation of the universal programme of PCV vaccination in Lithuania, it provides a basis for future comparisons of SPn carriage and serotype distribution between the pre- and post-vaccination era in the country.

\section{Acknowledgements}

This study was supported by an Investigator initiated Research grant from Pfizer.

\section{Conflict of interest}

None declared.

\section{Authors' contributions}

Vytautas Usonis had primary responsibility for the study design and development, data collection, outcome assessment and contributed in the writing of the manuscript. Sigita Petraitienè participated in the development of the protocol, nasopharyngeal sample and data collection, data analysis and writing of the manuscript. Daiva Vaičiūnienè contributed in nasopharyngeal sample and data collection and data analysis. Indrẻ Stacevičienè participated in nasopharyngeal sample and data collection, data analysis and writing of the manuscript. Tomas Alasevičius participated in nasopharyngeal sample and data collection, data analysis and writing of the manuscript. Jūrate Kirslienè was responsible for isolating Streptococcus pneumoniae and serotyping at the microbiology laboratory.

\section{References}

1. Bogaert D, De Groot R, Hermans PW. Streptococcus pneumoniae colonisation: the key to pneumococcal disease. Lancet Infect Dis. 2004;4(3):144-54. Available from: http:// dx.doi.org/10.1016/S1473-3099(04)00938-7 PMID:14998500

2. Pneumococcal conjugate vaccine for childhood immunization-WHO position paper. Wkly Epidemiol Rec. 2007;82(12):93-104.

3. Simell B, Auranen K, Käyhty H, Goldblatt D, Dagan R, O’Brien $\mathrm{KL}$, et al. The fundamental link between pneumococcal carriage and disease. Expert Rev Vaccines. 2012;11(7):841-55. Available from: http://dx.doi.org/10.1586/erv.12.53 PMID:22913260
4. Niedzielski A, Korona-Glowniak I, Malm A, Mielnik-Niedzielska G. Distribution of vaccine serotypes among Streptococcus pneumoniae colonizing the upper respiratory tract in healthy pre-school children in south-east Poland. Otolaryngol Pol. 2012;66(6):403-6.

5. van der Linden M, Reinert RR, Kern WV, Imöhl M. Epidemiology of serotype 19A isolates from invasive pneumococcal disease in German children. BMC Infect Dis. 2013;13;70. Available from: http://dx.doi.org/10.1186/1471-2334-13-70 PMID:23384407

6. Sleeman KL, Griffiths D, Shackley F, Diggle L, Gupta S, Maiden MC, et al. Capsular serotype-specific attack rates and duration of carriage of Streptococcus pneumoniae in a population of children. J Infect Dis. 2006;194(5):682-8. Available from: http://dx.doi.org/10.1086/505710 PMID:16897668

7. Tamm E, Naaber P, Maimets M, Oona M, Kõljalg S, Lutsar I. Antimicrobial susceptibility and serogroup/serotype distribution of nasopharyngeal isolates of Streptococcus pneumoniae in healthy Estonian children in 1999-2003. Clin Microbiol Infect. 2007;13(8):824-6. Available from: http:// dx.doi.org/10.1111/j.1469-0691.2007.01743.x PMID:17474973

8. Dunais B, Bruno P, Carsenti-Dellamonica H, Touboul P, Dellamonica P, Pradier C. Trends in nasopharyngeal carriage of Streptococcus pneumoniae among children attending daycare centers in southeastern France from 1999 to 2006 . Pediatr Infect Dis J. 2008;27(11):1033-5. Available from: http://dx.doi. org/10.1097/INF.ob013e31817bb8cf PMID:18955896

9. Tóthpál A, Kardos S, Hajdú E, Nagy K, Linden M, Dobay 0. Nasal carriage of Streptococcus pneumoniae among Hungarian children before the wide use of the conjugate vaccine. Acta Microbiol Immunol Hung. 2012;59(1):107-18. Available from: http://dx.doi.org/10.1556/AMicr.59.2012.1.11 PMID:22510292

10. Petrosillo N, Pantosti A, Bordi E, Spanó A, Del Grosso M, Tallarida B, et al. Prevalence, determinants, and molecular epidemiology of Streptococcus pneumoniae isolates colonizing the nasopharynx of healthy children in Rome. Eur J Clin Microbiol Infect Dis. 2002;21(3):181-8.

11. Bogaert D, Engelen MN, Timmers-Reker AJM, Elzenaar KP, Peerbooms PGH, Coutinho RA, et al. Pneumococcal carriage in children in The Netherlands: a molecular epidemiological study. J Clin Microbiol. 2001;39(9):3316-20. Available from: http://dx.doi.org/10.1128/JCM.39.9.3316-3320.2001 PMID:11526169

12. Falup-Pecurariu O, Bleotu L, Zavarache C, Peled N, Anton O, Robu M, et al. Streptococcus pneumoniae nasopharyngeal colonization in children in Brasov, Central Romania: high antibiotic resistance and coverage by conjugate vaccines. Pediatr Infect Dis J. 2011;30(1):76-8. Available from: http:// dx.doi.org/10.1097/INF.obo13e3181f42bb6 PMID:20844463

13. Bogaert D, van Belkum A, Sluijter M, Luijendijk A, de Groot R, Rümke HC, et al. Colonisation by Streptococcus pneumoniae and Staphylococcus aureus in healthy children. Lancet. 2004;363(9424):1871-2. Available from: http://dx.doi. org/10.1016/S0140-6736(04)16357-5 PMID:15183627

14. Dainauskaitė AMJ, Janulaitienè M, Griškevičius A. (Analysis of Streptococcus pneumoniae serotypes that caused invasive infections in children under 5 year old in 2006 - 2011). 20062011 metais paplitusiu Streptococcus pneumoniae serotipu, kurie sukẻlè invazines infekcijas vaikams iki 5 metų, analizè. Pediatrija. 2012;5(59):20-4.

15. O'Brien KL, Wolfson LJ, Watt JP, Henkle E, Deloria-Knoll M, McCall N, et al. Burden of disease caused by Streptococcus pneumoniae in children younger than 5 years: global estimates. Lancet. 2009;374:893-902.

16. Ministry of Health of Lithuania (MoH). Lietuvos Respublikos vaikų profilaktinių skiepijimų kalendorius. [Calendar of prophylatic immunisations of children, Republic of Lithuania 2014 [July 07]].Vilnius: MoH. [Accessed 20 Mar 2015]. Lithuanian. Available from: http://www3.Irs.lt/pls/inter3/ dokpaieska.showdoc_p?p_id=466527

17. Dagan R. Serotype replacement in perspective. Vaccine. 2009;27(Supplement 3):C22-4.

18. World Health Organization (WHO). Laboratory methods for the diagnosis of meningitis caused by Neisseria meningitidis, Streptococcus pneumoniae, and Haemophilus influenzae. 2nd ed. Geneva: WHO; 1999. Available from: http://www.who.int/ csr/resources/publications/meningitis/whocdscsredc997.pdf

19. Principi N, Marchisio P, Schito GC, Mannelli S; Ascanius Project Collaborative Group. Risk factors for carriage of respiratory pathogens in the nasopharynx of healthy children. Pediatr Infect Dis J. 1999;18(6):517-23. Available from: http://dx.doi. org/10.1097/00006454-199906000-00008 PMID:10391181

20. Hill PC, Akisanya A, Sankareh K, Cheung YB, Saaka M, Lahai G, et al. Nasopharyngeal carriage of Streptococcus pneumoniae in Gambian villagers. Clin Infect Dis. 2006;43(6):673-9. Available from: http://dx.doi.org/10.1086/506941 PMID:16912937 
21. Katz A, Leibovitz E, Timchenko VN, Greenberg D, Porat N, Peled N, et al. Antibiotic susceptibility, serotype distribution and vaccine coverage of nasopharyngeal and oropharyngeal Streptococcus pneumoniae in a day-care centre in St. Petersburg, Russia. Scand J Infect Dis. 2007;39(4):293-8. Available from: http://dx.doi.org/10.1080/00365540600987741 PMID:17454891

22. Vestrheim DF, Høiby EA, Aaberge IS, Caugant DA. Impact of a pneumococcal conjugate vaccination program on carriage among children in Norway. Clin Vaccine Immunol. 2010;17(3):325-34. Available from: http://dx.doi.org/10.1128/ CVI.00435-09 PMID:20107006

23. Coles CL, Rahmathullah L, Kanungo R, Thulasiraj RD, Katz J, Santosham M, et al. Nasopharyngeal carriage of resistant pneumococci in young South Indian infants. Epidemiol Infect. 2002;129(3):491-7. Available from: http://dx.doi.org/10.1017/ So950268802007586 PMID:12558331

24. Feikin DR, Davis M, Nwanyanwu OC, Kazembe PN, Barat LM, Wasas A, et al. Antibiotic resistance and serotype distribution of Streptococcus pneumoniae colonizing rural Malawian children. Pediatr Infect Dis J. 2003;22(6):564-7. Available from: http://dx.doi.org/10.1097/01.inf.0000069787.33960.d6 PMID:12828156

25. Vallès X, Flannery B, Roca A, Mandomando I, Sigaúque B, Sanz $\mathrm{S}$, et al. Serotype distribution and antibiotic susceptibility of invasive and nasopharyngeal isolates of Streptococcus pneumoniae among children in rural Mozambique. Trop Med Int Health. 2006;11(3):358-66. Available from: http://dx.doi. org/10.1111/j.1365-3156.2006.01565.x PMID:16553916

26. Petraitiene S, Bernatoniene G, Murauskaite G, Erlendsdottir H, Bernatoniene J, Usonis V. Ivairių tipų streptokokų paplitimas vaikų, lankančių ikimokyklinio ugdymo istaigas, viršutiniuose kvèpavimo takuose. [Distribution of various types of streptococcal infection in nasopharyngeal carriage among the children's day care attenders]. Medicinos teorija ir praktika. 2008;14(1):87-92. Lithuanian. Available from: http://www.mtp. It/files/MEDICINA-2008-1-p_87-92.pdf

27. Mauricas M, Petraitienè S, Kvietkauskaitė R, Tamošiūnas V, Girkontaitè I, Usonis V. Streptococcus pneumoniae carriage and salivary antibodies induced by Pneumococcus in Vilnius preschool children. Acta medica Lituanica. 2009;16(3-4):1118. Available from: http://www.Imaleidykla.lt/publ/13920138/2009/3-4/111-118.pdf

28. Petraitienė S, Bernatonienė G, Murauskaitė G, Erlendsdottir H, Bernatonienė J, Usonis V. S. pneumoniae nešiojimas 2-7 metų Vilniaus vaikų nosiaryklèje. [Distribution of S. pneumoniae nasopharyngeal carriage among 2-7 years of age children in Vilnius]. Vaiku pulmonologija ir alergologija. 2009;XII(1):411930. Lithuanian.

29. Žemlicková H, Urbásková P, Adámková V, Motlová J, Lebedová V, Procházka B. Characteristics of Streptococcus pneumoniae, Haemophilus influenzae, Moraxella catarrhalis and Staphylococcus aureus isolated from the nasopharynx of healthy children attending day-care centres in the Czech Republic. Epidemiol Infect. 2006;134(6):1179-87. Available from: http://dx.doi.org/10.1017/So950268806006157 PMID:16684402

30. Tamm E, Naaber P, Maimets M, Oona M, Kõljalg S, Lutsar I. Antimicrobial susceptibility and serogroup/serotype distribution of nasopharyngeal isolates of Streptococcus pneumoniae in healthy Estonian children in 1999-2003. Clin Microbiol Infect. 2007;13(8):824-6. Available from: http:// dx.doi.org/10.1111/j.1469-0691.2007.01743.x PMID:17474973

31. Revai K, Mamidi D, Chonmaitree T. Association of nasopharyngeal bacterial colonization during upper respiratory tract infection and the development of acute otitis media. Clin Infect Dis. 2008;46(4):e34-7. Available from: http://dx.doi. org/10.1086/525856 PMID:18205533

32. Syrjänen RK, Kilpi TM, Kaijalainen TH, Herva EE, Takala AK. Nasopharyngeal carriage of Streptococcus pneumoniae in Finnish children younger than 2 years old. J Infect Dis. 2001;184(4):451-9. Available from: http://dx.doi. org/10.1086/322048 PMID:11471103

33. Loughlin AM, Hsu K, Silverio AL, Marchant CD, Pelton SI. Direct and indirect effects of $\mathrm{PCV}_{13}$ on nasopharyngeal carriage of PCV13 unique pneumococcal serotypes in Massachusetts' children. Pediatr Infect Dis J. 2014;33(5):504-10. Available from: http://dx.doi.org/10.1097/INF.0000000000000279 PMID:24670957

34. Abdullahi O, Nyiro J, Lewa P, Slack M, Scott JA. The descriptive epidemiology of Streptococcus pneumoniae and Haemophilus influenzae nasopharyngeal carriage in children and adults in Kilifi district, Kenya. Pediatr Infect Dis J. 2008;27(1):59-64. Available from: http://dx.doi.org/10.1097/ INF.obo13e31814da70c PMID:18162940

35. Korona-Glowniak I, Malm A. Characteristics of Streptococcus pneumoniae strains colonizing upper respiratory tract of healthy preschool children in Poland. ScientificWorldJournal. 2012;2012:732901.

36. Weinberger DM, Grant LR, Steiner CA, Weatherholtz $R$, Santosham M, Viboud C, et al. Seasonal drivers of pneumococcal disease incidence: impact of bacterial carriage and viral activity. Clin Infect Dis. 2014;58(2):188-94. Available from: http://dx.doi.org/10.1093/cid/cit721 PMID:24190895

37. Yagupsky P, Porat N, Fraser D, Prajgrod F, Merires M, McGee L, et al. Acquisition, carriage, and transmission of pneumococci with decreased antibiotic susceptibility in young children attending a day care facility in southern Israel. J Infect Dis. 1998;177(4):1003-12. Available from: http://dx.doi. org/10.1086/515239 PMID:9534975

38. Sulikowska A, Grzesiowski P, Sadowy E, Fiett J, Hryniewicz W. Characteristics of Streptococcus pneumoniae, Haemophilus influenzae, and Moraxella catarrhalis isolated from the nasopharynges of asymptomatic children and molecular analysis of S. pneumoniae and $\mathrm{H}$. influenzae strain replacement in the nasopharynx. J Clin Microbiol. 2004;42(9):3942-9. Available from: http://dx.doi.org/10.1128/ JCM.42.9.3942-3949.2004 PMID:15364973

39. Marchisio P, Gironi S, Esposito S, Schito GC, Mannelli S, Principi N; Ascanius Project Collaborative Group. Seasonal variations in nasopharyngeal carriage of respiratory pathogens in healthy Italian children attending day-care centres or schools. J Med Microbiol. 2001;50(12):1095-9. Available from: PMID:11761195

40. Ritchie ND, Mitchell TJ, Evans TJ. What is different about serotype 1 pneumococci? Future Microbiol. 2012;7(1):3346. Available from: http://dx.doi.org/10.2217/fmb.11.146 PMID:22191445

41. Bogaert D, Sluijter M, Toom NL, Mitchell TJ, Goessens WHF, Clarke SC, et al. Dynamics of pneumococcal colonization in healthy Dutch children. Microbiology. 2006;152(Pt 2):37785. Available from: http://dx.doi.org/10.1099/mic.0.28394-o PMID:16436426 